\title{
Umbilical cord haematoma and adrenal haemorrhage in a macrosomic neonate with anaemia
}

\author{
Ryan Michael McAdams, Shilpi Chabra
}

Department of Pediatrics, University of Washington, Seattle, Washington, USA

\section{Correspondence to}

Dr Ryan Michael McAdams, mcadams@uw.edu

Accepted 21 January 2016
CrossMark

To cite: McAdams RM, Chabra S. BMJ Case Rep Published online: [please include Day Month Year] doi:10.1136/bcr-2015214140

\section{DESCRIPTION}

A 32-year-old G2P1 female without a history of diabetes or infection vaginally delivered a full-term $4800 \mathrm{~g}$ (99th centile), large for gestation age male with complications of shoulder dystocia. On day 1 , blood was noted to ooze from his clamped umbilical cord (UC) with a darkish bulge noted near its insertion site (figure 1), consistent with a UC haematoma. Platelet count and coagulation studies were normal. The haematocrit was initially $37 \%$, but decreased to $32.1 \%$.

On day 2, a bluish discolouration was noted in the supraumbilical region (figure 2), which did not correspond to any abdominal radiograph or ultrasound (US) findings. Incidentally, an avascular cystic lesion $(23 \times 20 \times 12 \mathrm{~mm} ; 2.9 \mathrm{~mL})$ was seen on US in the right suprarenal region suggesting adrenal haemorrhage (AH). The asymptomatic neonate was discharged home (day 3) with a haematocrit of $34.2 \%$. Follow-up US studies demonstrated the same cystic lesion with increased internal echoes

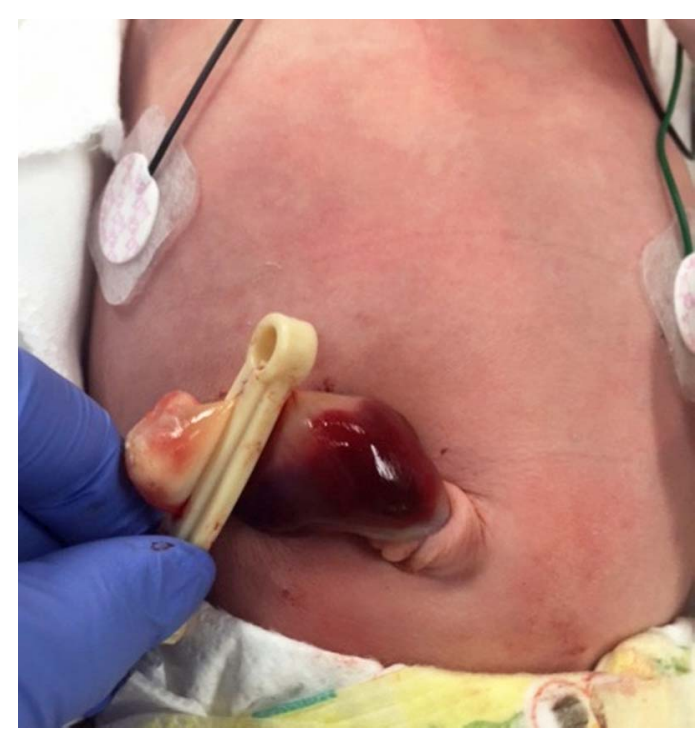

Figure 1 Umbilical cord haematoma.

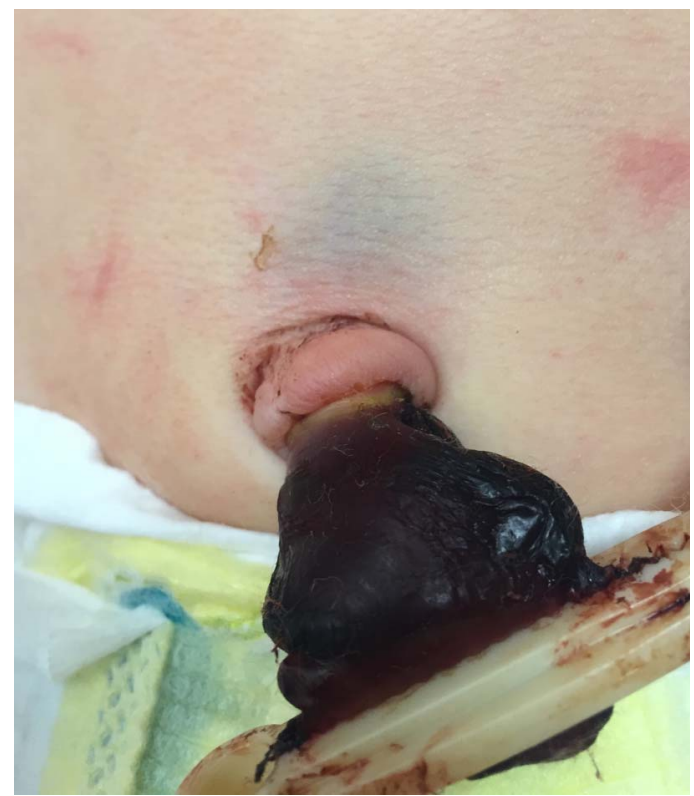

Figure 2 Bluish discolouration at the supraumbilical region.

(figure 3) consistent with an evolving right $\mathrm{AH}$ (day 10), which resolved by day 30 .

Macrosomia (birth weight $>4500 \mathrm{~g}$ ) is commonly associated with birth complications including shoulder dystocia, hypoglycaemia and intra-abdominal organ injury, such as $\mathrm{AH}$, which may cause postnatal anaemia. ${ }^{1}{ }^{2}$ Similarly to this case, $\mathrm{AH}$ is often asymptomatic unless large or bilateral. UC haematoma, a rare pregnancy/labour complication, may be associated with fetal morbidity and mortality. Risk factors include infection and/or trauma associated with invasive procedures/ birthing process, with the majority associated with venous vascular wall alterations with and without an associated inflammatory vasculopathy. ${ }^{3}$ In this case, the supraumbilical discolouration was most likely due to blood tracking from the UC haematoma along the umbilical fascial plane. 


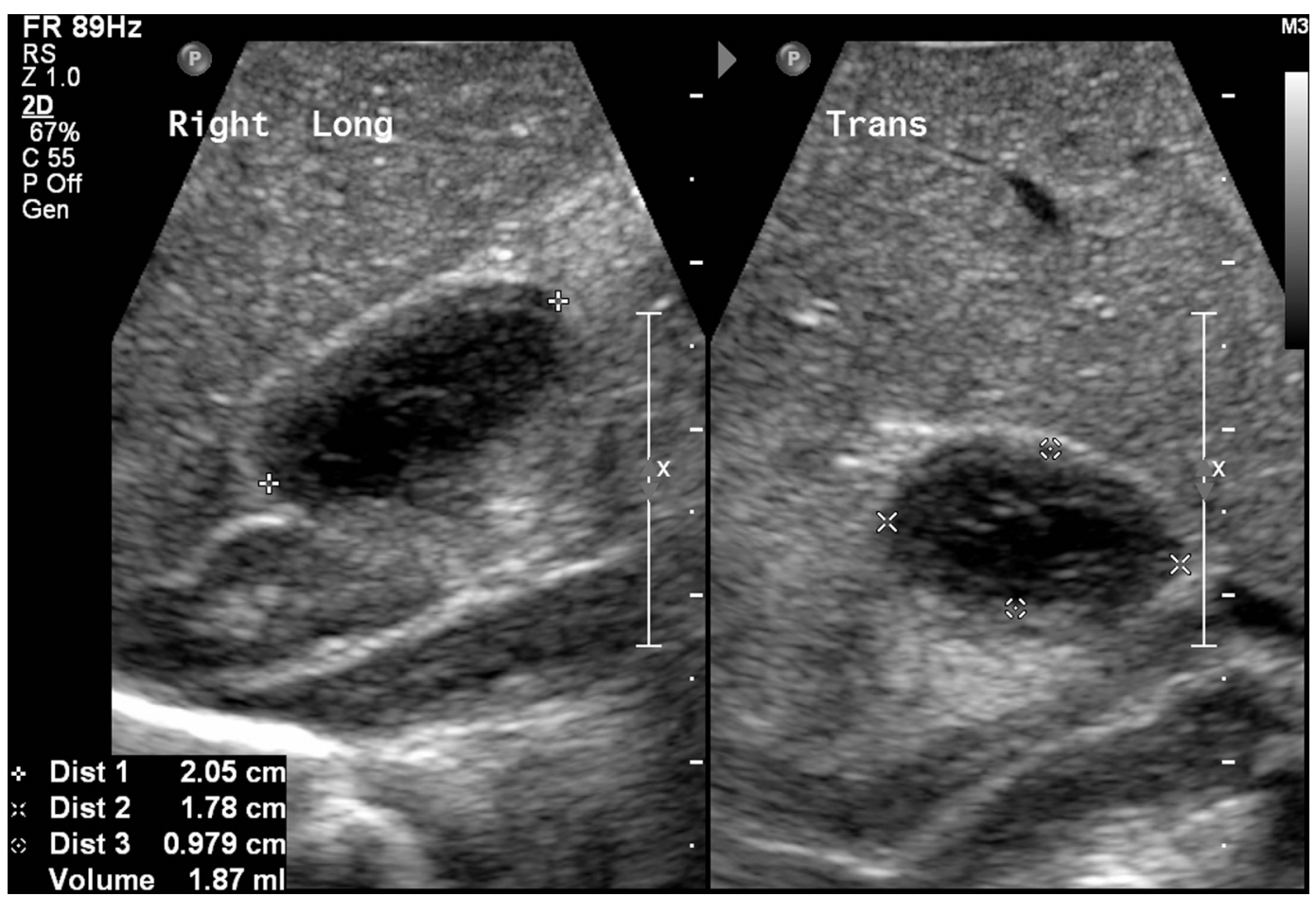

Figure 3 Abdominal ultrasonography showing a cystic-appearing hypoechoic heterogeneous mass consistent with right adrenal gland haemorrhage. There was no vascular abnormality on Doppler examination.

\section{Learning points}

- Macrosomia increases the risk for birth complications such as adrenal haemorrhage and, although not previously reported, may be a risk factor for umbilical cord haematoma, which emphasises the importance of careful evaluation of internal organs in cases of birth trauma where umbilical cord haematoma is also present.

- Following a difficult delivery, the presence of postnatal anaemia in a macrosomic newborn should raise suspicion of an adrenal haemorrhage.

- Abdominal ultrasound can be a valuable early diagnostic tool in patients with suspected umbilical cord haematomas to evaluate the proximal umbilical cord to exclude other abnormalities (eg, omphalocoele) and to assess for intra-abdominal organ injury, such as adrenal haemorrhage.
Contributors RMMCA and SC participated in writing up the case report, reviewing the manuscript, and editing the manuscript.

Competing interests None declared.

Patient consent Obtained.

Provenance and peer review Not commissioned; externally peer reviewed.

\section{REFERENCES}

1 Gyurkovits Z, Kálló K, Bakki J, et al. Neonatal outcome of macrosomic infants: an analysis of a two-year period. Eur J Obstet Gynecol Reprod Biol 2011;159:289-92.

2 Akin MA, Coban D, Doganay $S$, et al. Intrahepatic and adrenal hemorrhage as a rare cause of neonatal anemia. J Perinat Med 2011;39:353-4.

3 Gualandri G, Rivasi F, Santunione AL, et al. Spontaneous umbilical cord hematoma: an unusual cause of fetal mortality: a report of 3 cases and review of the literature. Am J Forensic Med Pathol 2008;29:185-90.

Copyright 2016 BMJ Publishing Group. All rights reserved. For permission to reuse any of this content visit http://group.bmj.com/group/rights-licensing/permissions.

BMJ Case Report Fellows may re-use this article for personal use and teaching without any further permission.

Become a Fellow of BMJ Case Reports today and you can:

- Submit as many cases as you like

- Enjoy fast sympathetic peer review and rapid publication of accepted articles

- Access all the published articles

- Re-use any of the published material for personal use and teaching without further permission

For information on Institutional Fellowships contact consortiasales@bmjgroup.com

Visit casereports.bmj.com for more articles like this and to become a Fellow 